\title{
Niewymuszona usługa seksualna w zamian za korzyść w pracy. Aspekty prawne
}

\section{Legal aspects of unforced sex in exchange for benefit at work}

\author{
dr hab. Irena Boruta
}

Streszczenie Casus niewymuszonego seksu za korzyść w pracy dowodzi, że ochronie przed dyskryminacją nie podlegają, w zasadzie, najwięksi przegrani tej sytuacji, tj. osoby, które wskutek zaistnienia seksu za pracę utraciły możliwość uzyskania przysporzenia korzyści. Zdaniem autorki, zmianie tej sytuacji służyłoby m.in. przejęcie z prawa antydyskryminacyjnego zmiany reguły dowodzenia i uznanie, że to pracodawca musiałby udowodnić, iż nie dopuścił się złamania zasad współżycia społecznego, jeśli zostałoby uprawdopodobnione, że doszło do seksu za korzyść w pracy.

Słowa kluczowe: niewymuszony seks za korzyść w pracy, dyskryminacja, molestowanie, molestowanie seksualne, domniemanie dyskryminacji, ciężar dowodu w sprawach na tle dyskryminacji.

Summary Unforced sex in exchange for an advantage at work is in fact indifferent from the point of view of antidiscrimination law. This indicates the shortcomings of this right. In particular, those employees whose employer has not granted benefits remain without anti-discrimination protection. They should at least be able to benefit from the exemption from the obligation to take evidence, as provided for in the anti-discrimination law in case if this person would seek protection based on a civil law violation of the principles of social coexistence.

Keywords: unforced sex in exchange for work benefits, discrimination, harassment, sexual harassment, presumption of discrimination., the burden of proof.

str. 2-6

\section{Bibliografia}

Adamiec, M. Kożusznik, B. (2000). Zarządzanie zasobami ludzkimi. Kraków: Wydawnictwo AKADE.

Boruta, I. (1996). Równość kobiet i mężczyzn w pracy w świetle prawa Wspólnoty Europejskiej. Implikacje dla Polski. Łódź.

Boruta, I. (2019a). Molestowanie a dyskryminacja. Zagadnienia prawne. W druku.

Boruta, I. (2019b). Numerus clausus podstaw dyskryminacji. W druku.

Fredman, S. (1992). European Community Discrimanation Law: a Critique. Industrial Law Journal, (2), https://doi.org/10.1093/ilj/21.2.119

Jędrzejko, M. (2006). Prostytucja — skala i charakter zjawiska w świetle badań. W: Prostytucja jako problem spoleczny, moralny $i$ zdrowotny. Pułtusk-Warszawa: Akademia Humanistyczna im. Aleksandra Gieysztora. Oficyna wydawnicza ASPRA-JR.

McKinnon, C. (1979). Sexual Harassment On Working Women.New Haven: Yale University Press.

Sztobryn, J. Gieruszkiewicz, J. (2004). Psychologiczne aspekty prostytucji. Łódź. 